\title{
Pacemakerrel, illetve ICD-vel rendelkezö betegek perioperatív menedzsmentje
}

\author{
Miklós Márton', Babik Barna², Sághy László', Pap Róbert \\ ${ }^{1}$ SZTE, II. sz. Belgyógyászati Klinika és Kardiológiai Központ, Elektrofiziológiai Részleg, ${ }^{2}$ Aneszteziológiai és \\ Intenzív Terápiás Intézet, Szívsebészeti Részleg, Szeged
}

Levelezési cím: Dr. Miklós Márton, e-mail: miklosm91@gmail.com

Hat évtized telt el az első pacemaker-implantáció óta. Ezalatt az idő alatt a beültetett eszközök használata világszerte elérhetővé és mindennapossá vált a megfelelő indikációs körben alkalmazva. Ezért mára az orvostudomány számos területén dolgozó szakember kezel nap mint nap beültetett eszközzel rendelkező betegeket. Gyakran előfordul, hogy egy-egy beteg gyógyításában több társszakma együttműködésével lehet csak az optimális eredményt elérni. Ilyen a pacemakeres, illetve ICD-s betegek mütétek és számos egyéb beavatkozás körüli ellátása. Jelen állásfoglalásban ezen betegek perioperatív menedzsmentjének kulcspontjait foglaljuk össze rövid elméleti háttér leírásával, de fő hangsúlyt a gyakorlati teendőkre helyezve, mely nemcsak az elektrofiziológusok és kardiológusok, hanem az aneszteziológusok és sebészek számára is segítséget nyújthat.

Kulcsszavak: pacemaker, ICD, CIED, EMI, perioperatív menedzsment, mágnesválasz, pacemaker-programozás

\section{Perioperative management of patients with implanted pacemaker or ICD}

The first pacemaker was implanted six decades ago. Since then implanted devices have become available and common in the proper indications. Nowadays a lot of physicians take care of patients with implanted devices day by day. During the treatment of a patient it is not rare, that physicians of different specialties have to work together to reach the best solution. The perioperative management of a patient with pacemaker or ICD is one of these situations. This script gives the cornerstones of the treatment to the electrophysiologists and cardiologists as well as the anesthesiologist and surgeons with a brief theoretical summary also.

Keywords: pacemaker, ICD, CIED, EMI, perioperative management, magnet mode, pacemaker programming

Az első pacemaker-beültetés óta eltelt 60 év alatt mind a pacemaker, mind az ICD (implantábilis kardioverter defibrillátor) implantáció világszerte és Magyarországon is rutinbeavatkozássá vált (1). A technika fejlődésével és az eszközös terápia terjedésével egyre több beteg esik át implantáción. Emiatt a mindennapi orvosi tevékenység során nemcsak az elektrofiziológusok és kardiológusok találkoznak eszközzel rendelkező betegekkel, hanem az aneszteziológusok, sebészek, belgyógyászok, radiológusok, onkológusok, háziorvosok

\section{Rövidítések:}

AHA: American Heart Association; ATP: Antitchycardia Pacing; CIED: Cardiovascular Implantable Electronic Device; CRT-D: Cardiac Resynchronisation Therapy-Defibrillator; CRT-P: Cardiac Resynchronisation Therapy-Pacemaker; ECT: Elektrokonvulzív Terápia; ECV: Electric Cardioversion; EMI: Elektromágneses Interferencia; EP: Elektrofiziológia; ERI: Electiv Replacement Indicated; GI: Gasztrointesztinális; HRS: Heart Rhythm Society; ICD: Implantálható Cardioverter Defibrillátor; ILR: Implantable Loop Recorder; MR: Mágneses Rezonancia; RF: Radiofrekvenciás; S-ICD: Subcutan ICD; TENS: Transcutan Electric Nerve Stimulation; TUNA: Transurethral Needle ablation; TURP: Transurethral Resection of the Prostate 
is (2). Jelen közlemény célja, hogy egységes kezelési stratégiát alakítsunk ki a pacemakerrel, illetve ICD-vel (összefoglalóan: CIED, cardiac implantable electronic device) rendelkező betegek esetén a mütét előtti, mütét alatti és mütét utáni, összefoglalóan a perioperatív teendőkröl. A legmegfelelöbb és a beteg érdekeit maximálisan szem előtt tartó ellátást csak a társszakmák folyamatos kommunikációjával és együttműködésével lehet elérni, éppen ezért jelen leirat ugyanannyira fontos az aneszteziológusok és sebészek, mint a kardiológusok, illetve elektrofiziológusok számára.

$\mathrm{Az}$ irodalmat áttekintve láthatjuk, hogy a témával kapcsolatban született publikációk döntő többsége esetriport. Randomizált vizsgálatok ilyen témában nem születtek, ezért jelen leirat sem fogalmaz meg evidenciaszinteket. Adataink nagy része a téma szakértőinek véleményén alapul. Az egyetlen konszenzus dokumentum a 2011-ben megjelent HRS/AHA-ajánlás, amelyre a legtöbb témában megjelent publikáció, így az alábbi magyar kiadvány is támaszkodik (3).

Emiatt minden eset egyéni elbírálást és kezelési stratégiát igényel. A perioperatív periódus komoly veszélyeket magában rejtö időszak, mivel rövid idő alatt több munkacsoport észleli és adja át egymásnak a beteget. Egyegy átadáskor óhatatlanul információvesztés történhet. Ezt elkerülendő minden elektív mütét előtt javasolt a beteget gondozó EP- (elektrofiziológiai) munkacsoport és a mútétet végző munkacsoport (aneszteziológus és sebész) közötti megbeszélés. Ennek során kölcsönös információcsere történik, amely részeként a sebész és aneszteziológus beszámol a tervezett mütét típusáról, a kezelési stratégiáról, a műtét helyéről és várható hosszáról, majd az EP-csoport meghatározza az adott helyzetben a beültetett eszközzel kapcsolatos teendöket. A műtét előtti megbeszélést követően nem minden esetben szükséges a CIED lekérdezése, EP-munkacsoporttal nem rendelkező intézmények esetén a legtöbb esetben a korábbi dokumentációk áttekintése is elegendő a megfelelő kezelési stratégia kialakításához.

\section{Speciális perioperatív problémák CIED esetén}

\section{Elektromágneses interferencia}

A leggyakoribb tényező, amely a CIED-ek diszfunkcióját okozhatja. Az elektromágneses interferencia (EMI) akkor jön létre, amikor különböző elektromos árammal működő berendezések által generált elektromágneses tér befolyásolja egy másik eszköz, jelen esetben pacemaker vagy ICD müködését (4). Bármilyen készülék képes EMI létrehozására, amely 0 és $109 \mathrm{~Hz}$ közötti radiofrekvenciás hullámot bocsát ki. A mütétek körüli időszakban számos eszközt használunk, amely potenciálisan elektromágneses interferenciát okozhat, ezért ebben a periódusban fokozott figyelmet kell fordítani az esetleges EMI okozta diszfunkciók kivédésére. Az EMI hatását befolyásoló tényezők közé tartoznak az elektromágneses sugárzás tulajdonságai, a készülék és az elektromágneses mező közötti távolság, a készülék anyaga, bevonata, érzékenysége és a különböző védőés szürőmechanizmusok. Az EMI kiküszöbölésére irányuló effortokat összefoglaló néven elektromágneses kompatibilitásnak hívjuk (EMC). Bipoláris elektródák esetén az anód és a katód igen közel helyezkedik el egymáshoz, mindkettő az elektródán, így minimálisra csökken az esélye az EMI felléptének. Néhány esetben azonban továbbra is találkozhatunk unipoláris elektródával. Ezek föleg epikardiális, illetve régebbi rendszereknél fordulnak elö. Unipoláris elektróda esetén az elektródavég a katód és a generátor az anód, így jóval nagyobb esély van EMI létrejöttére, mert praktikusan a rendszer antennaként viselkedik (5). Az alábbiakban összefoglaljuk a leggyakrabban EMI-t okozó hatásokat. Az MR-vizsgálatok, illetve a radioterápia és a CIED-ek kapcsolatát jelen összefoglalás nem részletezi.

\section{Elektrokauterizáció}

Elektrokauterizáció során 100-5000 kHz frekvenciájú áramot használnak vágásra, illetve koagulálásra. Az elektromos energia monopoláris, illetve bipoláris rendszeren keresztül kerülhet leadásra. Bipoláris rendszer esetén a sebészi eszköz két vége között történik meg az energialeadás, így minimális az esély arra, hogy EMI fellépjen a mütét során. Egyedül akkor kerülhet rá sor, ha az applikációkat közvetlenül a generátorra adják le. A szemészeti és mikrosebészeti mütétek kivételével azonban ritkán használnak bipoláris rendszert, az unipoláris rendszerek jóval szélesebb körben alkalmazottak. Unipoláris rendszer esetén a vágóeszköz egy kauterizációs kés, amely az energiát leadja, majd ez a testen keresztül „áramlik vissza” a neutrális elektródához, melyet a beteg teste alá helyeznek a mütét elött. A perioperatív időszakban leggyakrabban EMI-t okozó hatás a monopoláris elektrokauterizáció, amely hatással lehet a CIED-ek müködésére. A leggyakoribb hatások közt az inhibíció, a téves antitachycardia-terápia leadása és az ún. resetting szerepel. Mindazonáltal megfelelő odafigyeléssel ezek a hatások is ritkák. A legtöbb publikáció alapján készülék-diszfunkciót okozó interferencia csak akkor alakul ki, ha az applikációk a generátorhoz közelebb, mint $15 \mathrm{~cm}$-re történnek. A köldök alatt végzett beavatkozásoknál megfelelő neutrális elektróda-elhelyezés mellett - a combok alá - nem kell számítani számottevő EMI-re. Rövid - kevesebb, mint 4 sec-os - applikációk, alacsony energia és bipoláris rendszer használatával szintén csökkenteni tudjuk az esetleges CIED-diszfunkció kialakulásának esélyét. Az alábbiakban EMI hatására kialakuló CIED-diszfunkciókat vesszük sorra.

\section{Oversensing}

A leggyakoribb hatás, amely EMI hatására létrejöhet elektrokauterizáció során. „Demand” üzemmódba programozott készülék esetén (AAI/VVI/DDD mód) a zaj okozta túlérzékelés a pacemaker-ingerlés inhibíci- 
óját okozhatja, amely pacemaker-dependens betegnél szignifikáns bradycardiához vagy asystoliához vezethet. Rövid applikációk (max. $4 \mathrm{sec}$ ) használatával hemodinamikai megingással járó bradycardia kialakulása megelőzhető. Hosszabb kauterizációs idő mellett a CIED átkapcsolhat „noise reversion” módba, amely esetén aszinkron ingerlés indul egészen addig, amíg a zaj meg nem szünik. Kétüregi (VDD/DDD) üzemmódban a pitvari csatornán kialakuló zaj hatására magas kamrai frekvenciájú ingerlés alakulhat ki, vagy téves pitvari tachycardia-detekció következtében "mode switch” - VVI üzemmódba való kapcsolás - jöhet létre. ICD-k esetén szintén téves detekció alakulhat ki, amelyre terápialeadás (ATP vagy sokk) történhet, amely malignus kamrai ritmuszavar kialakulását is okozhatja. Az oversensing elkerülhető a készülék aszinkron módba programozásával és ICD-k esetén az antitachycardia terápiák felfüggesztésével.

\section{Rate response diszfunkciók}

Az ún. rate responsive funkciók lényege, hogy a készülék alkalmazkodni tud a megnövekedett fizikai igénybevételhez azáltal, hogy különböző algoritmusokkal érzékeli a fizikai aktivitás élettani jeleit, így növeli az ingerlési frekvenciát. Egy ilyen mechanizmus a percventiláció érzékelése, ahol az érzékelés impedancia alapú. EMI hatására szívfrekvencia-emelkedés léphet fel. Elkerülése érdekében a rate responsive funkciókat a műtét idejére ki lehet kapcsolni.

\section{Reset}

Ritkán fordul elő EMI kapcsán. Jobbára ionizáló sugárzás okozza a készülék biztonsági üzemmódba való átkapcsolását. A biztonsági üzemmód beállításai gyártónként különbözöek, azonban közös bennük, hogy a készülék VVI-módba kapcsol magas kimenő feszültség mellett. ICD-k esetén az antitachycardia-terápia (sokkleadás) megmarad. A Boston Scientific cég által gyártott egyes ICD-k esetén „visszafordíthatatlan meghibásodás" esetén ún. Safety Core módba kapcsol, amelyet követően a készülék interrogálást követően csak az antitachycardia-mód ki- vagy bekapcsolását tudjuk elvégezni. A későbbiekben a generátor cseréje szükséges. A készülék interrogálása nélkül leginkább a bázisfrekvencia megváltozása jelezheti, hogy a készülék biztonsági módba kapcsolt.

\section{Generátorsérülés}

Igen ritkán fordul elő, mert a gyártók egyik fő törekvése, hogy a készüléket ellenállóvá tegyék a külső elektromos energiával szemben. Az ICD-k kevésbé érzékenyek külső behatásokra, mint a pacemakerek. Leggyakoribb okok, amelyek a generátor sérüléséhez vezethetnek:

- Elektrokauterizáció a készüléken vagy közvetlen közelében.

- Elektródasérülés.

- A konnektor szigetelésének sérülése.
Emiatt a készülék közelében végzett mütétek során az alábbi óvintézkedések szükségesek:

- Ha lehetséges bipoláris rendszer használata.

- Unipoláris rendszer esetén a neutrális elektródát úgy kell elhelyezni, hogy az áram a készüléktöl minél meszszebb „húzzon” át.

- Alacsonyabb kimenő energiaszint használata.

\section{Stimulációs küszöb (threshold) emelkedés}

Ritkán előforduló jelenség, amelyet az elektróda-szívizom kapcsolat megváltozása okozhat olyan esetekben, amikor az unipoláris applikáció közel történik a készülékhez. Veszélye, hogy a korábban beállított kimenő feszültség nem lesz elegendő a szívizom ingerléséhez.

\section{Elektromos kardioverzió (ECV)}

ECV során nagy energia kerül leadásra a CIED közelében, amely ritkán a készülék „back up” módba való kapcsolását eredményezheti. Szintén ritkán előforduló jelenség az ECV-t követő akut vagy szubakut threshold-emelkedés, amely legtöbbször átmeneti jelenség. Ezen zavarok kivédhetők az alábbi intézkedésekkel: antero-posterior elektródafelhelyezés alkalmazása antero-laterális pozíció helyett; az elektródák legalább 8 $\mathrm{cm}$-re helyezkedjenek el a generátortól. Az ECV után a beteg csak a készülék interrogálását követően hagyhatja el a monitorizált zónát. Elektromos kardioverziót elméletileg ICD-vel is el lehet végezni, azonban van olyan tanulmány, amely alapján ennek effektivitása alacsonyabb, mint a transcutan kardioverzióé (6). Az ICD-vel végzett kardioverzió ellen szól továbbá, hogy minden egyes sokkleadás csökkenti a generátor élettartamát.

\section{Radiofrekvenciás abláció}

A monopoláris elektrokauterizációhoz hasonlóan az energialeadás a katétervégről a testen keresztül a neutrális elektródába történik. Gyakran előforduló következmény az under-, illetve oversensing. Ritkán resetting és „back up" módba kapcsolás is elöfordul (7). Pacemaker-dependens beteg esetén a beavatkozás előtt a készüléket aszinkron módba kell kapcsolni, illetve ICD-k esetén az antitachycardia-terápiákat fel kell függeszteni. A CIED-et a beavatkozást követően interrogálni célszerü.

\section{Elektrokonvulzív terápia (ECT)}

Gyakran fordul elö a beavatkozást követően sinus tachycardia, ami miatt ICD-k esetén az antitachycardia-terápiazónák újraprogramozása megfontolandó, illetve a ritkán előforduló oversensing miatt az antitachycardia-terápiák felfüggesztése is megfontolandó. Szintén az oversensing miatt pacemaker-dependens betegek esetén a készülék aszinkron módba programozása szükséges.

\section{Litotripszia}

Mivel többnyire a CIED-töl távol történik, az interakció esélye csekély. A litotripsziás sugár a generátortól minél távolabb essen. A pitvari ingerlés felfüggesztése 
szükségessé válhat, ha a litotriptor triggereli az R-hullámot. A beavatkozás alatt folyamatos monitorozás szükséges. Aritmia kialakulása esetén a beavatkozás terminálása szükséges. Csak fellépő inhibíció esetén szükséges mágnes felhelyezése.

\section{TUNA (transurethral needle ablation) és TURP (transurethral resection of the prostate)}

Ritka szövődmény az oversensing. Mágnes felhelyezésével, illetve a rövid kauterizációkkal lehet kivédeni.

\section{Gl-endoszkópos beavatkozások}

Elektrokauterizáció használata esetén oversensing előfordulhat, ezért ugyanúgy kell eljárni, mint köldök feletti műtét esetén. Kapszulaendoszkópia során káros hatásról ez idáig nem számoltak be, mégis az eszköz leiratában kontraindikációként szerepel a CIED.

\section{TENS (transcutaneus electrical nerve stimulation) és gerincvelö-stimulátorok \\ Oversensing gyakran előfordul. Pacemaker-dependens betegekben alkalmazásuk nem ajánlott.}

\section{Mágnesválasz pacemakerek esetén}

Mütétek során gyakran alkalmazunk mágnest a CIED-ek átmeneti átprogramozására. Általánosságban egy erős (90 Gauss), fánk alakú mágnes szükséges, melynek minden mütőblokkban rendelkezésre kell, hogy álljon. Gyártónként eltérően reagálnak a készülékek mágnes felhelyezésére. Az esetek túlnyomó többségében aszinkron (A00/V00/D00) módba kapcsolnak egy mágneskapcsoló aktiválódásával, és amíg a mágnes a generátoron van, úgy is maradnak. Ezzel elkerülhető az inhibíció, illetve a tracking és rate reszponzív funkciók aktiválódása is. Egyes gyártók azonban programozható mágnesmóddal rendelkeznek (Biotronik, St. Jude, Boston), így a beavatkozás előtt meg kell győződni az aktuális mágnesválaszról. A mágnes felhelyezését hangjelenség nem követi, így a frekvencia és az EKG változása alapján bizonyosodhatunk meg arról, hogy a készülék mágnesmódba kapcsolt. Megfelelő telepfeszültség esetén gyártótól függően 85-100/min közötti aszinkron ingerlés indul, a LivaNova (Sorin) és St. Jude készülékeknél az ingerlés kimenő feszültsége is változik. ERI-ben lévő készülékek esetén a frekvencia $65-85 /$ min között változik. A mágnes indokolatlan felhelyezése azonban veszéllyel járhat, amenynyiben például a beteg intrinsic ritmusa és az aszinkron ingerlés ritmusa vetélkedik. Ebben az esetben malignus kamrai ritmuszavarok is kialakulhatnak.

\section{Mágnesválasz ICD-k esetén}

Mágnes felhelyezésével a készülék tachycardia-detekciója és ezzel a terápialeadás felfüggesztésre kerül.
Egyes Boston Scientific készülékek kivételével a terápia felfüggesztése megszűnik, amint a mágnest eltávolítjuk a készülékről. ICD-k esetén azonban a pacemaker-funkció nem vált aszinkron módba mágnes felhelyezésével, ezt csak a készülék interrogálásával és átprogramozásával lehet elérni. Mágnes felhelyezésekor a Medtronic ICD-k szirénához hasonló hangot adnak ki néhány másodpercig, míg a Boston Scientific készülékek a mágnesmód ideje alatt végig "sípolnak” az R-hullámmal szinkronban. Egyes gyártók programozható mágnesmóddal rendelkeznek (Biotronik, St. Jude, Boston), így a beavatkozás előtt meg kell gyöződni az aktuális mágnesválaszról. Ehhez a korábbi ICD-ellenőrzések dokumentációjának áttekintése, vagy a készülék aktuális interrogálása szükséges az EP-munkacsoport által.

\section{Rizikóbecslés}

Minden műtét előtt elengedhetetlen elvégezni, hogy megfelelő perioperatív stratégiát tudjunk kialakítani a CIED esetleges átprogramozása szempontjából. A legfontosabb, EMI következtében kialakuló hatás a túlérzékelés, emiatt rizikóbecslő stratégiánkat az oversensing elkerülésére kell kihegyezni. Figyelembe kell vennünk a mütét anatómiai lokalizációját, az applikációk várható időtartamát, a neutrális elektróda pozícióját, a mútét esetleges kiterjesztésének esélyét. Az alábbi stratégia az infraclavicularisan elhelyezett generátorokra vonatkozik. Föleg gyermekeknél, epikardiális rendszerek esetén a generátort epigastrialisan helyezik el, ezekben az esetekben mindenkor egyéni döntést kell hozni, amely gyakrabban fog a készülék mütét elötti átprogramozása mellett szólni. Infraclavicularisan elhelyezkedő telepek esetében a legnagyobb kockázatot a készülék $15 \mathrm{~cm}$-es környezetében leadott applikációk jelentik. Számos irodalmi adat alapján a köldök vonala alatt végzett beavatkozások esetén megfelelő neutrális elektróda pozicionálással (glutealis tájék vagy a combok alá) alacsony az esély a túlérzékelésre, míg a felső has, a mellkas, a nyak, az arc, a fej és a felső végtagok területén végzett mütétek esetén jelentősebb a rizikó. Ezek alapján kell az EP-csoportnak döntést hoznia az esetleges átprogramozásról. A rendelkezésre álló szakértői vélemények alapján a köldök alatt végzett beavatkozások során olyan alacsony az oversensing, ezáltal az inhibíció esélye, hogy még pacemaker-dependens betegeknél sem szükséges a pacemaker átprogramozása, csak szignifikáns inhibíció észlelését követően kell mágnessel aszinkron módba váltani. Természetesen mágnes azonnali elérhetősége elengedhetetlen ezekben az esetekben, illetve arról is meg kell győződni, hogy a mágnesmód be van e kapcsolva.

ICD-k esetén a köldök alatt végzett beavatkozásokat tekintve elfogadott megoldás, hogy az elektrokauterizáció előtt mágnes felhelyezését válasszuk a „szoros 
obszerváció" helyett. Ebben az esetben a tachycardia-detekció csak a legszükségesebb ideig szünetel, de az oversensing okozta téves detekciótól, és ezáltal helytelen terápia leadástól sem kell félnünk. Így a legbiztonságosabb megoldást tudjuk biztosítani a beteg számára. Vannak olyan esetek, amikor mágnes felhelyezése nem elegendő, a készülék mütét előtti átprogramozása elengedhetetlen. Ilyen például, amikor az ICD-vel rendelkező beteg pacemaker-dependens. Ebben az esetben mágnes felhelyezésével nem váltana aszinkron módba az ingerlés, ami szignifikáns bradycardiához, asystoliához vezethet.

Szakértői vélemények alapján az alsó végtagon végzett beavatkozások során (ha a neutrális elektróda ugyanazon a végtagon van) olyan alacsony az oversensing esélye, hogy a CIED átprogramozása, vagy mágnes rutinszerủ felhelyezése sem pacemakerek, sem ICD-k esetén nem szükséges, tekintet nélkül a pacemaker-dependenciára.

Nem lehet elégszer hangsúlyozni, hogy a fentebb vázolt stratégia csak akkor követhetö, ha mágnes azonnali felhelyezésére lehetőség van. Ezekben az esetekben is elengedhetetlen a defibrillálási, illetve transzkután ingerlési készültség.

\section{Perioperatív stratégia}

A fentebb leírt rizikóbecslés alapján dönthetjük el, hogy egy-egy beavatkozásnál milyen stratégiát válasszunk (1. ábra).

- Az ICD tachycardia-detekcióját nem kell minden esetben felfüggeszteni a beavatkozás alatt, ahogy a pacemakert sem kell minden esetben aszinkron módba kapcsolni pacemaker-dependens betegben sem.
- Mágnes használatával a pacemaker aszinkron módba kapcsol, míg az ICD felfüggeszti a tachycardia-detekciót.

- Az ICD mágnes felhelyezését követően nem változtatja meg az ingerlés módját, tehát nem vált aszinkron módba!

- Az alsó végtagokon végzett beavatkozásoknál átprogramozás és mágnes használata sem szükséges.

- Köldök alatt végzett beavatkozások esetén pacemakerrel rendelkező betegnél szoros monitorozás és mágnes elérhetősége esszenciális. Mütét előtti átprogramozás, vagy mágnes rutinszerủ felhelyezése nem szükséges pacemaker-dependens betegeknél sem.

- Köldök alatt végzett beavatkozások esetén ICD-vel rendelkező, nem pacemaker-dependens betegnél mágnes felhelyezése, ezzel a tachycardia-detekció felfüggesztése ajánlott.

- Köldök alatt végzett beavatkozások esetén ICD-vel rendelkező, pacemaker-dependens betegnél az ICD átprogramozása (tachycardia-detekció felfüggesztése és aszinkron ingerlés beállítása) elengedhetetlen.

- Köldök felett végzett beavatkozásoknál pacemakerrel rendelkező, nem pacemaker-dependens betegeknél mágnes azonnali elérhetősége szükséges, mágnes rutinszerü felhelyezése, vagy átprogramozás nem kell.

- Köldök felett végzett beavatkozásoknál pacemakerrel rendelkező, pacemaker-dependens betegeknél mágnes felhelyezése, vagy a készülék mütét előtti átprogramozása elengedhetetlen.

- Köldök felett végzett beavatkozásoknál ICD-vel rendelkező, nem pacemaker-dependens betegeknél mágnes felhelyezése, vagy a készülék mütét elötti programozása szükséges.

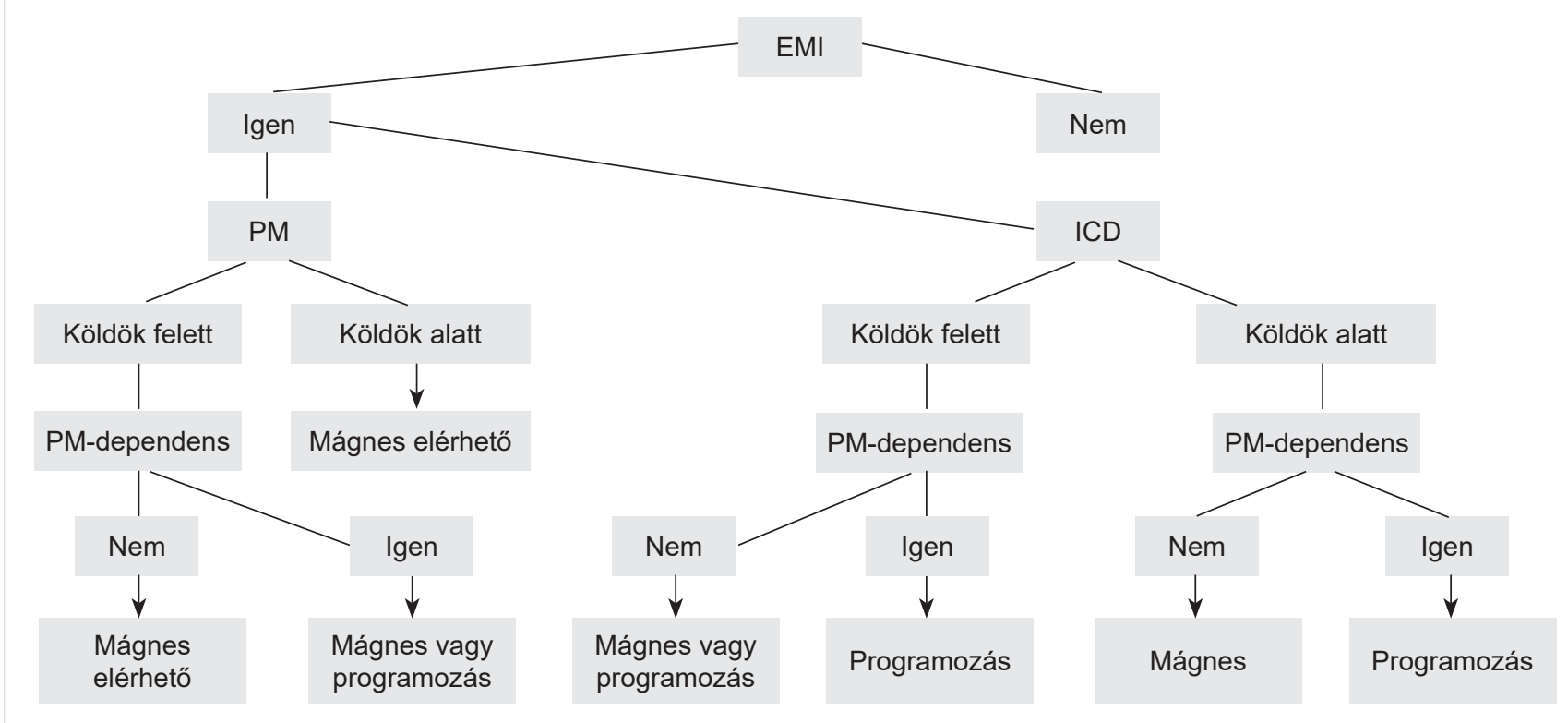

1. ÁBRA. Összefoglaló ábra a perioperatív CIED-programozási stratégiáról 
- Köldök felett végzett beavatkozásoknál ICD-vel rendelkezö, pacemaker-dependens betegeknél az ICD-t át kell programozni (tachycardia-detekció felfüggesztése és aszinkron ingerlés beállítása).

- Fentiekből következik, hogy pacemaker-dependens, ICD-s beteg mütétje csak az EP-munkacsoport közreműködésével (készülék programozása) végezhető biztonsággal.

- A CIED legutóbbi kontrollja ICD-k esetén legfeljebb 6 hónappal, pacemakerek esetén legfeljebb 1 évvel a beavatkozás előtt megtörtént.

Mágnes használata mellett szóló érvek között szerepel, hogy nem szükséges hozzá programozó és CIED-programozásban jártas szakember. Eltávolításával azonnal reaktiválódnak a korábban beálított funkciók, így pl. malignus kamrai ritmuszavar esetén az ICD-terápiát képes leadni. Ellenérvként felsorakoztatható a programozható mágnesmód, mágnes hiánya a mütőblokkban, illetve az esetlegesen rosszul felhelyezett, ezáltal nem effektív mágnesterápia.

\section{Elektív mútétek perioperatív menedzsmentje}

\section{Mútét elötti teendők}

A megfelelő kommunikáció az EP-munkacsoport és a mütétet végző munkacsoport (aneszteziológia és sebészet) között elengedhetetlen. Legkésőbb a beteg osztáIyos felvételekor ki kell, hogy derüljön, hogy CIED-del rendelkezik, ezért szükséges, hogy a sebész, illetve aneszteziológus minden esetben kérdezze meg a betegtöl, illetve fizikális vizsgálat során keresse az eszközt és az esetleges mútéti heget infraclavicularisan. Az eszköz azonosító kártyája, illetve az elvégzett mellkasröntgen segíthet a készülék típusának identifikálásában (pacemaker/ICD).

A mütétet végző munkacsoport által biztosított információ a következőket tartalmazza:

- A mütét típusa, anatómiai elhelyezkedése, a mütét kiterjesztésének lehetősége, iránya.

- A beteg pozíciója a mütőasztalon.

- A mütét ideje, helye, várható időtartama.

- A beavatkozást követő elhelyezés (posztoperatív megfigyelő, Intenzív osztály, kórterem).

- A monitorozott zónából való távozás ideje, a hazabocsátás tervezett ideje.

- Egyéb fontos, a műtétre vonatkozó információ (pl. monopoláris energia használata).

Az EP-munkacsoport által biztosított információ a következőkre terjed ki:

- A készülék típusa (pacemaker/ICD/CRT-P/CRT-D).

- Implantáció oka (PM: SSS/AV-blokk; ICD: primer/szekunder profilaxis).

- Implantáció három hónapon belül történt-e.

- Utolsó lekérdezés időpontja, ennek adatai (elem élettartama, programozási mód, minimum megengedett frekvencia, threshold).

- Pacemaker-dependencia kérdése.
- ICD-terápia zónák határai, ezekre adott terápiás válasz (ATP/sokk).

- Mágnesválasz programozhatósága, aktuális programozási mód.

- Választandó perioperatív stratégia.

\section{Mútét alatti teendők}

A beteg folyamatos monitorozására több, különböző elven müködő eszközt használjunk a téves detekció elkerülése céljából.

- Az EKG-monitorozás során pacemakermód beálítása a „double counting” elkerülésére.

- Folyamatos monitorizálás a mütét alatt.

- EKG-monitoron kívül folyamatos artériás nyomásmonitorizálás vagy pulzoximetria szükséges (kauterizáció során artefaktumok zavarják az EKG-monitort).

- Defibrillációs, illetve transzkután pacelesi készültség.

- A felső testfél vénáinak Seldinger-féle kanülálása fokozott körültekintéssel történjen, mert a müvelet közben a pacemaker-elektródák érintése érzékelési zavart okozhat.

- Mágnes azonnali elérhetősége.

A sebészek részéről az alábbi mútéttechnikai megoldások szükségesek:

- Bipoláris rendszer használata, amennyiben lehetséges.

- A neutrális elektróda megfelelő pozicionálása (gluteális tájék vagy combok alá).

- Rövid, maximum 4 sec-os applikációk használata legalább 2 sec szünettel két applikáció között.

\section{Mútét utáni teendők}

A beavatkozást követő időszakban legalább olyan szoros obszerváció szükséges, mint a mütét alatt. Ideális esetben a műtéti program első felében történik meg a CIED-del rendelkező beteg beavatkozása, így ha szükséges, a mütét utáni visszaprogramozásra még ezen a munkanapon lehetőség lesz. A következő esetekben a beteg folyamatos monitorizálása szükséges mindaddig, amíg a készülék interrogálása az EP-munkacsoport által meg nem valósult:

- Mütét előtt a készülék:

- aszinkron módba lett kapcsolva,

- a tachycardia-detekció fel lett függesztve.

- A beavatkozás alatt:

- hemodinamikai megingás történt,

- külső defibrillációra volt szükség,

- transzkután ingerlésre volt szükség,

- kardiopulmonalis reszuszcitáció történt.

- Köldök felett végzett, sürgősségi mütét után.

- Elektromos kardioverzió után.

- Radiofrekvenciás abláció után.

A beavatkozást követő egy hónapon belül szükséges a CIED interrogálása az alábbi esetekben:

- Monopoláris energiával végzett mütéteket követően, a fentebb felsoroltak kivételével.

- Elektrokonvulzív terápiát követően.

- Litotripsziát követően. 


\section{Sürgősségi mútétek perioperatív menedzsmentje}

\section{Mútét elötti teendők}

Miután észleltük, hogy a beteg CIED-del rendelkezik a következő lépésben meg kell határoznunk, hogy a készülék pacemaker vagy ICD:

- Anamnézis felvételével.

- Korábbi dokumentációk áttekintésével.

- A CIED azonosító kártyáján leírtak segítségével.

- A beteget gondozó EP-munkacsoporttal való kapcsolatba lépéssel.

- MRTG készítésével: ICD esetén a sokkelektróda jobb kamrában elhelyezkedő része kb. kétszer olyan vastag, mint a proximálisabb rész.

A mütét előtt készített 12 elvezetéses EKG segíthet meghatározni a pacemaker-dependencia kérdését. Ha minden P-hullám és/vagy QRS-komplexus előtt van spike, akkor azt kell feltételeznünk, hogy a beteg pacemaker-dependens.

\section{Mútét alatti teendők}

Az elektív mútéteknél leírtak hatványozottan fontosak a sürgősségi mütéteknél. Elengedhetetlen a beteg folyamatos EKG-monitorizálása és folyamatos artériás nyomásmérés vagy legalább pulzoximetria használata. Defibrillálásra és transzkután pacelésre is alkalmas elektródák mütét előtti felhelyezésével azonnal reagálni tudunk az esetlegesen fellépő bradycardiára vagy malignus kamrai tachycardiára is. Pacemaker-dependens betegeknél még lényegesebb a rövid, maximum 4 sec-os applikációk használata, ezzel oversensing okozta inhibíció esetén sem alakul ki hemodinamikai instabilitás az esetek döntő részében.

Pacemakerre vonatkozó speciális megfontolások:

- Pacemaker-dependens betegeknél a köldök felett végzett beavatkozásoknál mágnes felhelyezése, ezzel a készülék aszinkron módba kapcsolása szükséges.

- Nem pacemaker-dependens betegeknél a köldök felett végzett beavatkozásoknál mágnes azonnali elérhetősége szükséges.

- Pacemaker-dependens betegeknél a köldök alatt végzett beavatkozásoknál mágnes azonnali elérhetősége szükséges.

ICD-re vonatkozó speciális megfontolások:

- Köldök felett és köldök alatt végzett beavatkozásoknál is szükséges a mágnes felhelyezése, ezzel a tachycardia-detekció felfüggesztése.

- ICD-vel rendelkező, pacemaker-dependens betegek esetén kritikus jelentőséggel bír a rövid kauterizációs idő és a szoros monitorizálás, mert a készülék mágnes felhelyezésével nem vált aszinkron módba!

- Az alsó végtagokon végzett beavatkozások esetén mágnes azonnali elérhetősége szükséges.

Kritikus állapotú betegeknél, ha a CIED mütét előtti evaluációjára nincs idő, akkor a mütét elején mágnest kell felhelyezni a készülékre, és figyelni az EKG-n bekövetkező változást:
- Ha a készülék aszinkron módba vált, akkor pacemakerről van szó, és a mágnesmód be van kapcsolva.

- Ha a készülék nem vált aszinkron módba, akkor:

- ICD-vel rendelkezik a beteg és mágnes módba kapcsolt a készülék (egyes gyártóknál hangjelzés követi a mágnesmódba kapcsolást).

- ICD-vel rendelkezik a beteg és a mágnesmód ki van kapcsolva.

- Pacemakerrel rendelkezik a beteg és a mágnesmód ki van kapcsolva.

- A mágnes nem megfelelő erősségü, vagy rosszul lett felhelyezve.

\section{Mứtét utáni teendők}

A beteg folyamatos monitorizálása elengedhetetlen, amíg a készülék interrogálása meg nem történik:

- Amennyiben a beavatkozás alatt:

- hemodinamikai megingás történt,

- külső defibrillációra volt szükség,

- transzkután ingerlésre volt szükség,

- kardiopulmonalis reszuszcitáció történt.

- Köldök felett végzett, sürgősségi mütét után.

- Elektromos kardioverzió után.

- Radiofrekvenciás abláció után.

A beavatkozást követő egy hónapon belül szükséges a CIED interrogálása minden egyéb sürgősségi, monopoláris energiával végzett mútétet követően.

\section{Speciális eszközök}

Szubkután ICD (S-ICD)

A szubkután ICD megfelelő alternatíva azokban az esetekben, amikor a betegnek nincs pacemakerigénye, és ATP sem szükséges. A Boston Scientific által gyártott eszköz tachycardia-detekcióra, illetve sokk leadására képes $80 \mathrm{~J}$ energiával. Sokk leadását követően 30 secon keresztül bradycardia esetén 50/min frekvenciával pacemaker-funkciót is képes ellátni. Jobbára olyan esetekben választjuk ezt az eszközt, amikor az endovaszkuláris implantáció kontraindikált vagy nem lehetséges. A generátor a bal hónaljároknál helyezkedik el a hatodik bordaköz magasságában, míg az elektróda szubkután kerül bevezetésre a processus xyphoideusig horizontálisan, majd a manubriosternalis ízületig ventralisan. Az S-ICD-implantációk száma Magyarországon is évről évre növekszik, emiatt műtétek során is találkozhatunk vele. Perioperatív menedzsmentje a transvenosus ICDhez hasonló. Választható a készülék mútét előtti átprogramozása, vagy mágnes felhelyezése is. Utóbbi esetén a mágnest úgy kell felhelyezni, hogy félig „fedje” a generátort. Az S-ICD mágnesmódba való kapcsolását 60 sec-on át tartó „csipogó” hang jelzi (8).

\section{Implantálható Loop Recorder (ILR)}

A Medtronic cég által gyártott Reveal ILR-t bal oldalra parasternalisan a 4. bordaközben kell elhelyezni. A készülék folyamatos, egy elvezetéses EKG-regisztrációra és tárolásra képes. Implantációjára általában tisz- 
tázatlan eredetủ syncope vagy ismeretlen tachycardia esetén kerül sor. A készülék akár három éven keresztül is képes működni. Terápialeadási funkciója nincs. A perioperatív időszakban speciális teendőt nem igényel. A posztoperatív szakban történő küldések során a mütét ideje alatt fellépő EMI miatt téves detekció fordulhat elö, amelyet a rendszer pitvari vagy kamrai tachycardiaként aposztrofálhat.

\section{Irodalom}

1. Babik B. Perioperatív Betegellátás. Szerk: Tassonyi Edömér, Fülesdi Béla, Molnár Csilla; Medicina Kiadó; 2009. 2.3. A pacemakeres beteg.

2. Babik B. Aneszteziológia és Intenzív Terápia, Szerk: Bogár Lajos. Medicina Kiadó; 2008. 3.5.2. Nagy cardivascularis kockázatú beteg anesztéziája.

3. Crossley GH, Poole JE, Rozner MA, et al. Expert Consensus Statement on the perioperative management of patients with implantable defibrillators, pacemakers and arrhythmia monitors: facilities and patient management this document was developed as a joint project with the American Society of Anesthesiologists (ASA), and in collaboration with the American Heart Association (AHA), and the Society of Thoracic Surgeons (STS). Heart Rhythm 2011; 8: 1114-1154. doi: 10.1016/j.hrthm.2010.12.023

4. Beinart R, Nazarian S, Effects of external electrical and magnetic fields on pacemakers and defibrillators; from engineering principles to clincial practice. Circulation 2013; 128: 2799-809. doi: 10.1161/ CIRCULATIONAHA.113.005697

5. Stone ME, Salter B, Fischer A, Perioperative management of patients with cardiac implantable electronic devices. $\mathrm{Br} \mathrm{J}$ of Anesth 2011; 107 Suppl 1:i16-26. doi: 10.1093/bja/aer354

6. Limantoro I, Vernooy K, Weijs B, Pisters R, Debie L, Crijns HJ, Blaauw $Y$. Low efficacy of cardioversion of persistent atrial fibrillation with the implantable cardioverter-defibrillator. Neth Heart J 2013; doi: 10.1007/s12471-013-0474-z.

7. Arora L, Inampudi C, Perioperative management of cardiac rhyt$\mathrm{hm}$ assist devices in ambulatory surgery and non operating room anesthesia. Curr Opin Anesthesiol 2017; 30:676-681. doi: 10.1097/ ACO.0000000000000532

8. Cronin B, Essandoh MK, Update on Cardiovascular Implantable Electronic Devices for Anesthesiologists. J Cardiothorac Vasc Anesth 2017; S1053-0770. doi: 10.1053/j.jvca.2017.09.007

\title{
ESC Congress Munich 2018
}

\author{
25-29 August
}

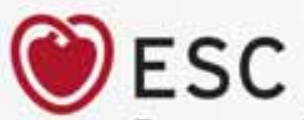

European Society of Cardiology

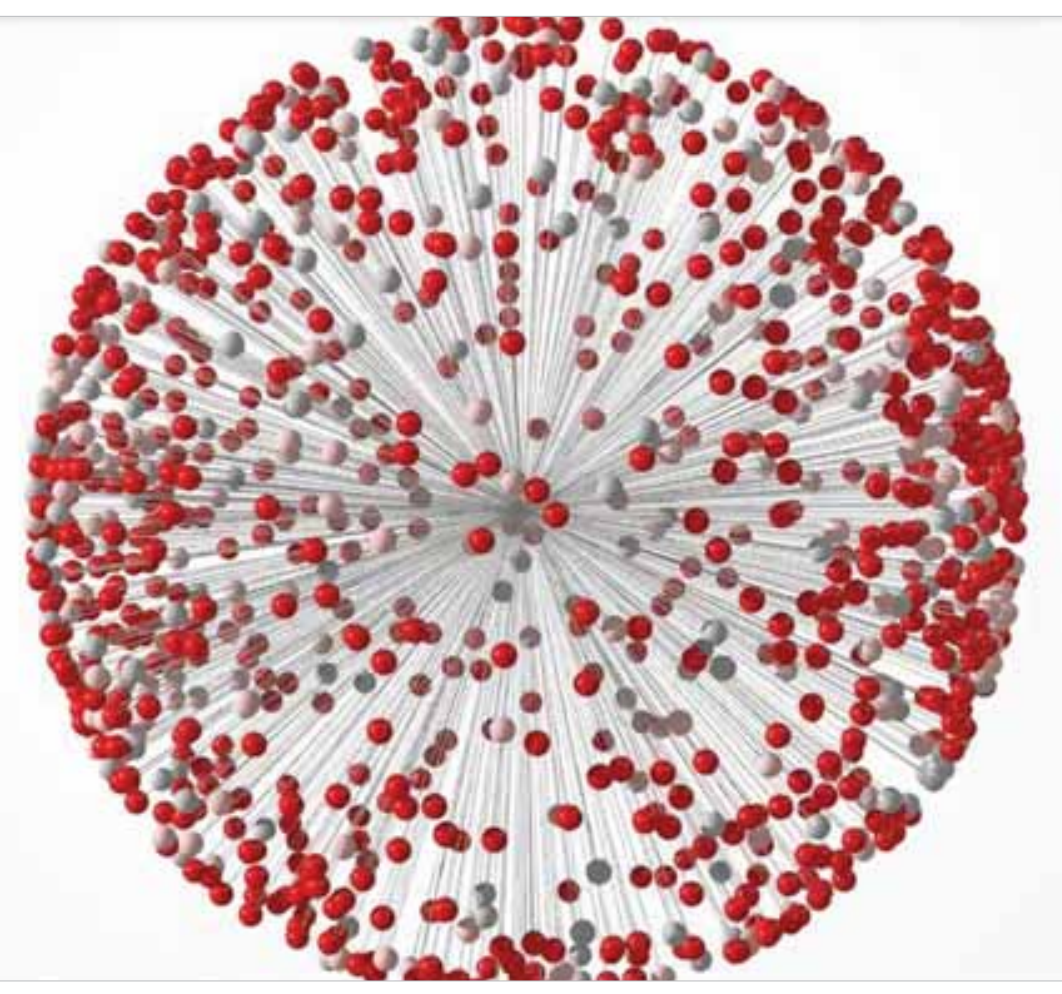

